\title{
A New Monogenean-ectoparasites Silurodescoides srivastavai n.sp. From Edible Fresh-water Cat Fish Wallago attu of District Balrampur, Uttar Pradesh, India.
}

\author{
Surya Prakash Mishra
}

Department of Zoology, Ganpat Sahai P.G. College Sultanpur, Uttar Pradesh, India.

To Cite this Article

Surya Prakash Mishra, "A New Monogenean-ectoparasites Silurodescoides srivastavai n.sp. From Edible Fresh-water Cat Fish Wallago attu of District Balrampur, Uttar Pradesh, India", International Journal for Modern Trends in Science and Technology, Vol. 07, Issue 01, January 2021, pp.- 65-68.

\section{Article Info}

Received on 22-November-2020, Revised on 18-December-2020, Accepted on 28-December-2020, Published on 03-January-2021.

\section{ABSTRACT}

The fresh-water fish Wallago attu (Bloch. And Schn.) was collected from local fish market of district Balrampur (U.P.) and examined 15 specimens, of which only one specimen was found infected with 17 specimens of said species. The site of infection being the gill filaments of the host. The present form differs from S. devraji, S. malabaricus and S.parvulus in having accessory pieces on dorsal anchors and presence of wings on dorsal anchors. Moreover, it differs from S. indicus, S octolytus, S. aori and S. sudhakari in having cephalic glands and different shape of copulatory complex and vagina. On subsequent study, the present form appear to be a new species of the genus Silurodescoides Gussev, 1974 and described as a new species and named Silurodescoides srivastavai $n$. sp. in the honor of Dr. C.B. Srivastava, Ex. Dy. Director, Zoological Survey of India, Kolkata.

KEYWORDS: Fresh-water, Monogenean ectoparasites, Silurodescoides srivastavai, Wallago attu.

\section{INTRODUCTION}

Monogenean occurs commonly as ectoparasites on the gills and skin of fishes and lower aquatic invertebrates. Monogenean are browsers that move about freely on the fish's body surface feeding on mucus and epithelial cells of the skin and gills; however, a few adult monogenean will remain permanently attached to a single site on the host. Monogenean undergo asexual mode of reproduction and multiply rapidly to form dense population on the gills of the host. The population structure of this monogenean, however, depends on a wide range of environmental factors; the relative importance of these factors varies from species to species and also within the same species depending on the host taxonomy and the nature of habitat (Chubb, 1977). Monogenean is a class of parasitic flatworms that are mainly ectoparasites of fishes but occasionally they are found as endoparasites (Gussev and Fernando, 1973).

Monogenean constitutes a group, which play an important role as pathogens of severe diseases (Hoffman, 1979 and Srivastava, 1980). This is because they affect those organs and tissues which are vital to the normal functioning such as gills and skin, the organs of respiration (Mishra, 2007, 
2014a). In majority of cases, monogenean cause dual type of injury to their hosts. Through their hooks and other organs of attachment, they break the continuity at the site of attachment and result is to localize hemorrhage (Mishra, 2008, 2014b). Monogenean infestations cause irritation and excessive mucus production and create an opening for bacterial invasion (Dubey, et. al. , 1990 and Mishra, 2020a). A few monogeneans on a healthy mature fish are not usually significant; however, moderate numbers can cause significant mortalities (Pandey and Mehta, 1986). When fish are exposed to environmental or behavioural stressors, the potential damage from monogenean is greater. Prevention of monogenean infestations by appropriate quarantine is preferable to treatment of the parasites after they have become established in a system (Pandey, 1973 and Mishra, 2020b).

Monogeneans are the most ubiquitous and abundant group of helmith parasites in the aquatic environment (Bychowsky, 1957 and Ivona, 2004). Monogeneans feed upon the blood and cells of ruptured tissues (Bychowsky, 1957; Mishra, 2015 and Bommakanti, 2016). Researchers have established that the volume of the blood sucked from the fish is quite appreciable and this leads to certain conditions like anemia and mortality (Lutta, 1941; Golovina, 1976 and Mishra, 2014c).

The genus Silurodiscoides (Achmerow, 1964 and Gussev, 1974) has been recorded and described in detail from the gills of teleost fishes of super family Siluroidae. Several workers like Yin and Sproston (1948); Jain (1957); Tripathi (1959); Achmerow (1964); Rajeshwari and Kulkarni (1983); Rizvi (1971); Sharma and Sheikh (1986); Gussev (1974) and Singh and Kumari, (1991) has reported different species of this genus from different teleost as different name. During the study of fresh-water monogenean of district Balrampur, we came across single infected specimen of Wallago attu, infected with monogenean belonging to the genus Silurodescoides (Achmerow, 1964 and Gussev, 1974). On subsequent study, the present form appears new to us and described here in as such.

\section{MATERIAL AND METHODS:}

The fishes for the present investigation were collected from fresh-water bodies and local fish market of district Balrampur, Uttar Pradesh, India. The monogenean were collected by Mizelle's freezing techniques. They were kept in refrigerator for 8 to 48 hours. The low temperature not only relaxes the worm but also help in automatic removal of mucus in which there flukes were entangled. Subsequently, the gills were removed, placed in separate tubes, half filled with water and shake vigorously. This solution now poured in clean petri-dish diluted with water and examined under binocular microscope. The worms thus collected were washed and fixed in hot $70 \%$ ethyl alcohol or $10 \%$ neutral formalin. Study of chitinoid hard parts were made in either temporary (glycerin) or permanent preparations. Permanent preparations were made after dehydrating through ascending grades of alcohol, clearing in xylene and mounting in Canada balsam. Camera Lucida sketches were made from permanent preparations within a week since the stain fades away in ten days.

\section{RESULT AND DISCUSSION:}

The body is elongated, measuring 0.66- 0.76 * $0.08-0.11 \mathrm{~mm}$. The head is bilobed having six pairs of head organs and two pairs of eye - spots. The posterior pair being slightly larger than the anterior one due to the presence of greater number of milanistic granules. The pharynx is well developed, rounded and muscular, measures 0.05 - $0.06 \mathrm{~mm}$ in diameter. At the postero - lateral sides of the pharynx there exists a group of darkly stained cephalic glands. The intestine is simple, bifurcated and caeca are united posteriorly.

The ovary is pear shaped, pre-testicular, pre-equatorial and measures $0.06-0.07 * 0.03-$ $0.04 \mathrm{~mm}$ in diameter. Vagina is present at posterior level of the seminal vesicle, which is circular in outline and leading in to a funnel like duct. The opening is guarded by a set of two semicircular valves. Vitelline follicles are distributed throughout the body from behind pharynx up to the peduncle of the haptor.

The testis is single, oval, post-equatorial, post-ovarian, inter-caecal and measures 0.09 $0.10 * 0.06-0.07 \mathrm{~mm}$. A fine vas deferens arises from the anterior border of testis. A pear shaped seminal vesicle is present in the region of copulatory complex, measuring $0.04-0.05 * 0.01$ $0.02 \mathrm{~mm}$. The copulatory complex consists of a cirrus proper and accessory piece of the cirrus. The cirrus proper is straight type, chitinoid double walled, tube like structure and measures 0.126 $0.129 \mathrm{~mm}$. Accessory piece of the cirrus is long, double walled, tube like structure, measuring $0.076-0.079 \mathrm{~mm}$. At the base of it, there exists a circular and muscular pouch, the gonotype 
measuring $0.017-0.018 \mathrm{~mm}$. One pair of prostate gland is present at the base of cirrus.

The haptor is well marked off from body proper and measures $0.12-0.13 * 0.014-0.015 \mathrm{~mm}$. Armature of the haptor consists of two pairs of anchors, two transverse bars and 14 marginal hooklets. Each dorsal anchor is varicorhinus type consists of bifurcated base, a semicircular shaft, a long pointed tip. They are further strengthened by small wings at the shaft. Besides this they also have an accessory piece at their base. The dorsal anchors are connected with each other through a strong dorsal transverse bar, which is anchoroid type. The ventral anchors also have deeply bifurcated base, nanus type, tapering shaft and curved pointed tips. The ventral anchors are connected with each other through a set of 2 ventral transverse bar giving a $\mathrm{V}$ shaped appearance. Seven pairs of dactylogyrus type, crochet shaped, marginal hooklets are superficially embedded in the margins of haptor. Details of measurements are as follows:

Dorsal Anchor: Total length of anchor is 0.041 $0.042 \mathrm{~mm}$; Length of anchor root is $0.022-0.023$ $\mathrm{mm}$; Length of anchor shaft is $0.035-0.036 \mathrm{~mm}$ and Length of anchor point is $0.018-0.019 \mathrm{~mm}$. Ventral Anchor: Total length of anchor is 0.024 $0.025 \mathrm{~mm}$; Length of anchor root is $0.008-0.009$ $\mathrm{mm}$; Length of anchor shaft is $0.046-0.047 \mathrm{~mm}$ and Length of anchor point is $0.007-0.008$. Dorsal Transverse Bar: Total length is $0.039-0.040$ and Total width of ventral bar is $0.006-0.007 \mathrm{~mm}$. Ventral Transverse Bar: Total length of bar is $0.047-0.048 \mathrm{~mm}$ and Total width is 0.004 $0.0041 \mathrm{~mm}$. Marginal Hooklets: Total length is $0.027-0.028 \mathrm{~mm}$; Length of blade is $0.004-0.005$ $\mathrm{mm}$ and Accessory piece measurement is 0.012 $0.013 \mathrm{~mm}$.

The present form belongs to genus Silurodescoides (Achmerow, 1964) Gussev, 1973, on the basis of presence of a pair of separate ventral transverse bars.

The present form differs from Silurodescoides devraji, Silurodescoides malabaricus and Silurodescoides parvulus in having an accessory piece on dorsal anchors and presence of wings on dorsal anchors. Moreover, it differs from Silurodescoides indicus, Silurodescoides octolytus, Silurodescoides aori and Silurodescoides sudhakari in having cephalic glands in having different shape of copulatory complex and vagina.

However, it differs from Silurodescoides gussev Singh et. al., 1992 in having less number of head organs, absence of reproductive glands, difference in shape of copulatory complex and difference in shape of marginal hooklets. The present form is therefore, described as a new species viz. Silurodescoides srivastavai $\mathbf{n}$. sp. in the honor of Dr. C. B. Srivastava, Ex. Dy. Director, Zoological Survey of India, Kolkata.
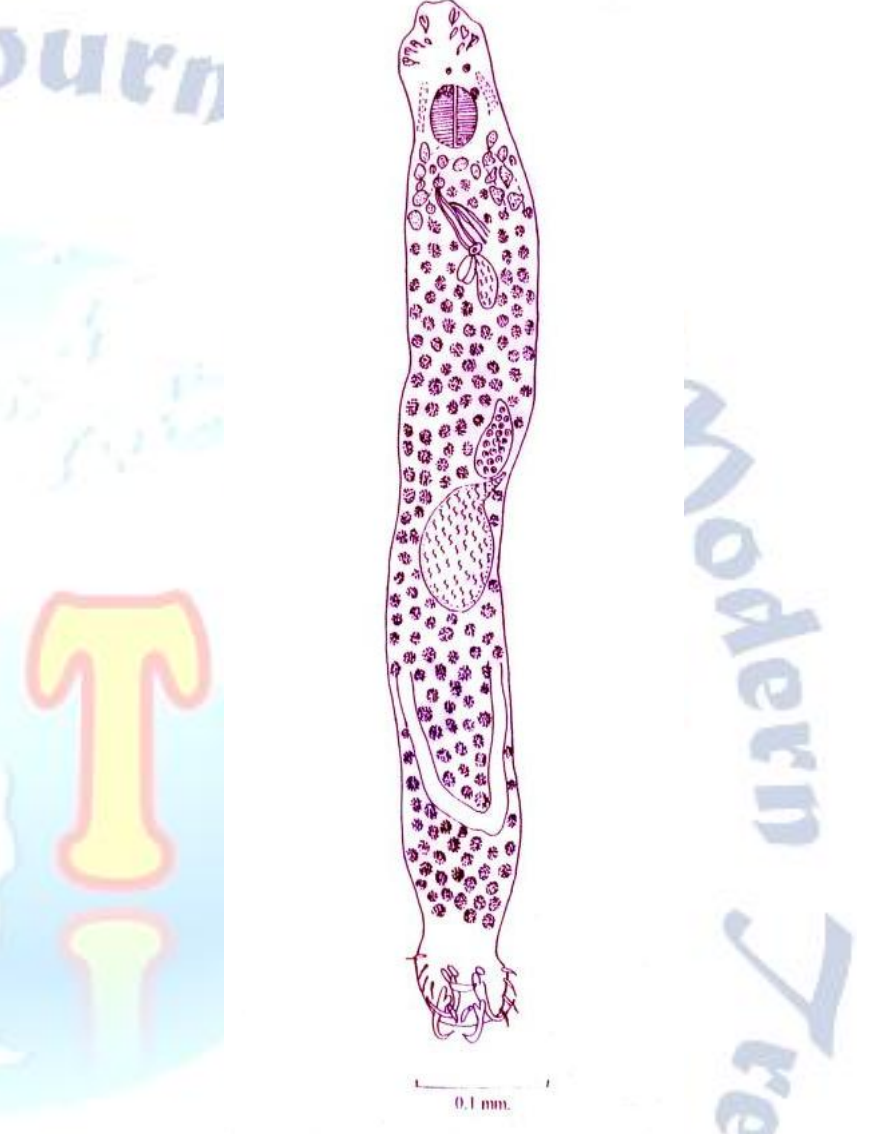

\section{REFERENCES:}

1. Achmerow, A. K. (1964): Evolution of the middle attachment apparatus in the monogenean suborder-Dactylogyrus. Trudy gelmint. Lab. 14: 69-79.

2. Bommakanti, L. (2016): Prevalence of Gyrodactylus sp. in Channa punctatus (Bloch, 1793) Monogenean Ecto-parasite Family: Gyrodactylidae at Lower Manair Dam. Int. J. Curr. Microbiol. App. Sci. Vol. 5 (9): 496-507.

3. Bychowsky, B. E. (1957): Monogeneans their systematics and phylogeny (Russian) T. Ransl. English by W.J. Hargis (Ed.), A.I.B., Washington, DC. 626 pp.

4. Chubb, D.K. (1977): Seasonal occurrence of helminthes in freshwater fishes. Part I. Monogenean. Adv. Parasitol., 15: 133-199.

5. Dubey, A., Gupta, A.K. and Agarwal, S.M. (1990): Studies on monogenean parasites in fresh water fishes at Raipur, III. Three new species of the genus Gyrodactylus Nordmann (1832). Ind. J. Helmithzol., 42: 1-8.

6. Gussev, A.V. and Fernando, C.H. (1973): Dactylogyridae, Monogenoidea, from the stomach of fishes. Folia Parasitol. 20: 207-212. 
7. Gussev, A.V. (1974): Fresh water Indian Monogenoidea. Principles of systematics, analysis of the world fauna and their evolution. Indian J. Helmith. 25 \& 26: 1-241.

8. Hoffman, G.L. (1979): Helmith parasite. In: Plumb, I. A. (ED.) Principal Diseases of Farm-raised Catfish. Southern Cooperative Series No. 225, pp. 40-58.

9. Ivona, M. (2004): Monogenean parasites in Adriatic cage-reared fish. Acta Adriatica. 5: 65-73.

10. Jain, S.L. (1957): Mizelleus indicus n. gn. (subfamilyTetraonchinae) from the gill filament of Wallagonia attu (Bloch.) Ann. Zool. Agra. 2: 56-62.

11. Lutta, A.S. (1941): Vospallenie zhabru Acipenser nudiventris vyzvannoe, monogenetcheskin sosal. Shchikem Nitzchia sturionis (inflammation of gills of Acipenser nudiventis caused by the monogenetic trematode Nitzchia sturionis). Zoology. Zhurnal. 20: 520-527.

12. Mishra, Surya Prakash (2007): A new monogenean, Ancylodiscoides amethii, n. sp. from fresh water fish Notopterus notopterus. J. Liv. World Vol. 14 (1): 13-17.

13. Mishra, S.P. and Pande, P.N. (2008): A new monogenean Metahaliotrema Tripathi n. sp. from fresh water fish Rita rita (Ham.).J.PAS Zoological Sciences Vol. 14: 40-45.

14. Mishra, Surya Prakash (2014a): A new Monogenea Diclidophora srivastavai n. sp. from fresh water fish Setipinna phasa. Int. J. Curr. Microbiol. App. Sci. Vol. 3 (12): 201-204.

15. Mishra, Surya Prakash (2014b): A new monogenean Hamatopeduncularia saketensis $\mathrm{n}$. sp. from fresh water fish Wallago attu. Int. J. Multidis. Res. Dev. Vol. 1 (7): 244-246.

16. Mishra, Surya Prakash (2014c): A New Monogenea Paramazocraes nawabganjensis n. sp. from fresh water fish Eutropichthyes vacha. Int. J. Eng. Sci. Inv. Res. Dev. Vol. 1 (5): 190-193.

17. Mishra, Surya Prakash (2015): On a new species of Monogenea Diplozoon chauhani n. sp. (Diplozooidae) from Indian fresh water food fish Cirrhinus mrigala. Int. J. Fish. Aqua. Stud. Vol. 2 (4): 140-141.

18. Mishra, Surya Prakash (2020a): Monogenetic Trematode Infestations in Indian Cat Fishes of River Gomti at District Sultanpur, Uttar Pradesh, India. Int. J. Modern. Trends in Science and Technology. Vol. 6 (8): 120-124.

19. Mishra, Surya Prakash (2020b): Monogenetic trematode infestations in Indian major carps of Ayodhya division, Uttar Pradesh, India. J. Emer. Tech. Innov. Res. Vol. 7 (7): 1920-1928. 20. Pandey, K.C. (1973): Studies on the monogenetic trematodes of India III. On a new species of Diplozoon Nordmann, 1822 from Catla catla (Ham.). Indian J. Zool. Vol. 14: $147-148$.

21. Pandey, K.C. and Mehta, T. (1986): Studies on some new monogenetic trematode of Wallago attu (Bloch.) at Meerut, Uttar Pradesh, India. Proc. $2^{\text {nd }}$ Nat. Conv. Young Scientists. 114-132. 22. Rajeshwari, J.S. and Kulkarni, T. (1983): On a new species of Bychowskyella singhi from the gills of fresh water fish Wallago attu from Hyderabad, A.P., India. Proc. Indian Acad. Parasitol. Vol. 4: 49-53.

23. Rizvi, S.S.H. (1971): Monogenea of Pakistan fishes Ancylodescoides mystusi n. sp. and Ancylodescoides aori n. sp. from gills of Mystus aor (Ham.).

24. Sharma, R.K. and Sheikh, Y.K. (1986): On the infection of Silurodescoides (Achmerow, 1964) Gussev, 1974 (Monogenea: Dactylogyridae) in the fishes of river Yamuna at Etawah, Uttar Pradesh. National Symposium on new Dimensions Parasitology. 56: 33.

25. Singh, H.S. and Kumari, M. (1991): Some observation on fresh water Dactylogyrid Silurodescoides sp. Indian Journal of Parasitology. Vol. 16: 157-164.

26. Singh, H.S.; Kumari, M. and Agarwal, S. (1992): On some known and unknown Monogeneans from Wallago attu (Bloch.
And Schn.) Functional and Developmental Morphology. Vol. 2: 85-88.

27. Srivastava, C. B. (1980): Estimation of helminthic infections. Proceedings Workshop Technology Parasitol. Zool. Survey of India, pp. 29-31.

28. Tripathi, Y. R. (1959): Monogenetic trematodes of fishes from India. Indian J. Helmith. Vol. 9: 1- 149.

29. Venkatnarsaiah, J. and Kulkarni, T. (1980): New monogenetic trematodes of the genus Calydescoides Young, 1969 from gills of Nemipterus japonicas. Proc. Indian Acad. Parasit. Vol. 1: 20-22.

30. Yin, Wen- Ying and Sproston, N.G. (1948): Studies on the monogenetic trematodes of China, 1-5 Sinensia. Vol. 19: 57-85.

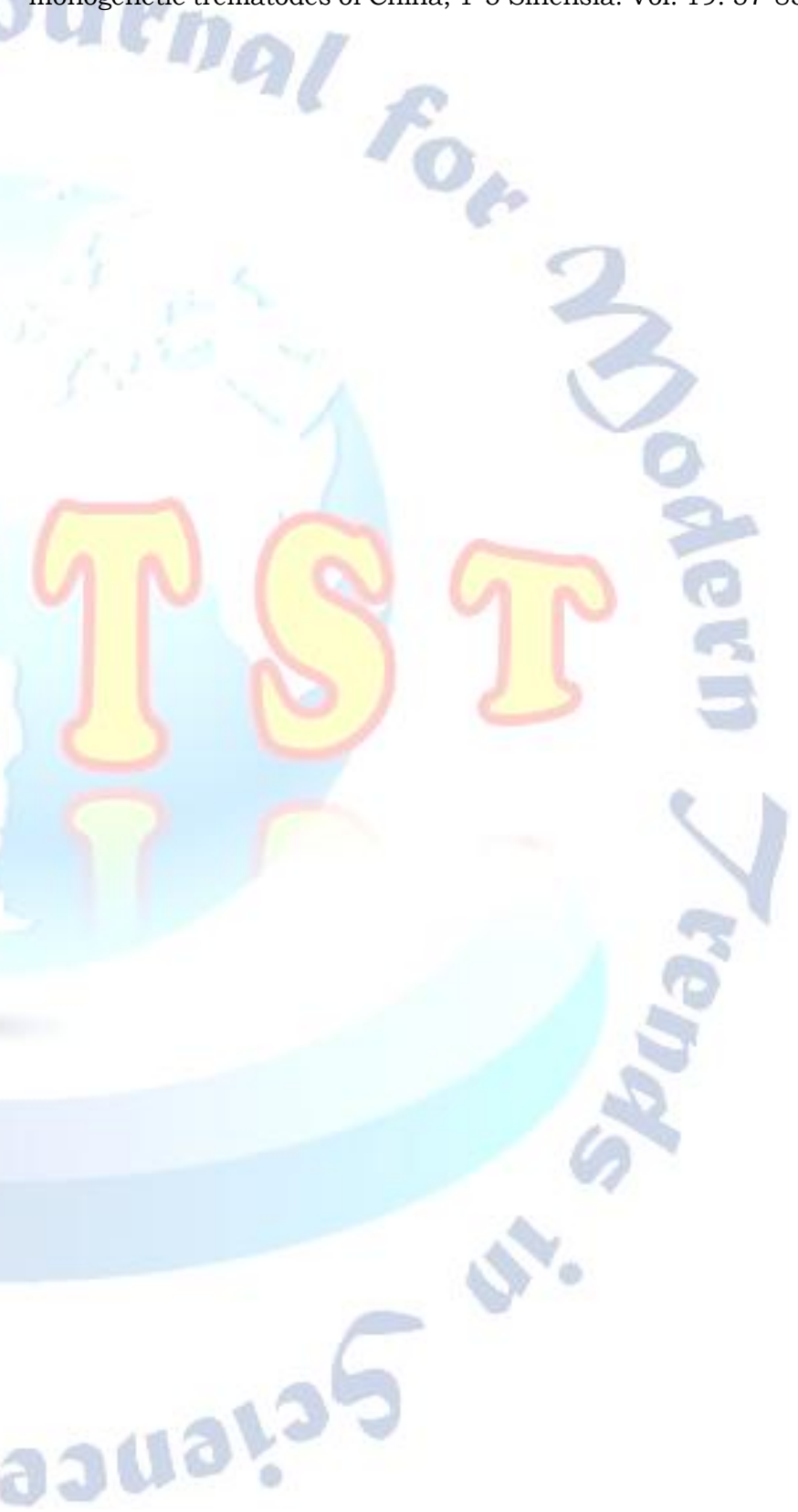

